\title{
FORMATION OF PROFESSIONAL COMPETENCIES OF TOURISM PROFESSIONALS DURING IMPLEMENTATION OF PROGRAMS FOR THE ORGANIZATION OF RECREATIONAL SERVICESIN THE COURSE OF PRODUCTION PRACTICE
}

\section{ФОРМУВАННЯ ФАХОВИХ КОМПЕТЕНТНОСТЕЙ ФАХІВЦІВ ІЗ ТУРИЗМУ ПІД ЧАС УПРОВАДЖЕННЯ ПРОГРАМ ІЗ ОРГАНІЗАЦІЇ РЕКРЕАЦІЙНИХ ПОСЛУГ У ХОДІ ВИРОБНИЧОЇ ПРАКТИКИ}

Larysa BEZKOROVAYNA,

Doctor of Pedagogical Sciences,

Associate Professor
Лариса БЕЗКОРОВАЙНА, доктор педагогічних наук, доцент

Ivbeskorovaynaya@gmail.com

https://orcid.org/0000-0001-9502-9604

Olha LITVINOVA-HOLOVAN,

Candidate of Pedagogical. Sciences, Senior Lecturer
Ольга ЛІТВІНОВА-ГОЛОВАНЬ, кандидат педагогічних наук, старший викладач

amlady.litvinova@gmail.com https://orcid.org/0000-0002-2647-8147

\section{Pavlo PYPTIUK,}

Candidate of Pedagogical, Sciences, Associate Professor
Павло ПИПтюк, кандидат педагогічних наук, доцент

piptykpavel@gmail.com

https://orcid.org/0000-0002-8188-2046

Viktoria BABII,

Candidate of Physical Education and

Sports, Associate Professor
Вікторія БАБІЙ, кандидат наук з фізичного виховання та спорту, доцент bviktoria6622@gmail.com

https://orcid.org/0000-0002-6143-3358

Zaporizhia National University

66, Zhukovskogo St., Zaporizhzhia, 69600, Ukraine
Запорізький національний університет

$\triangle$ вул. Жуковського, 66, м. Запоріжжя, 69600, Україна

Original manuscript received: November 09, 2021

Revised manuscript accepted: December 06, 2021

\section{ABSTRACT}

The article describes emotional intelligence of a university lecturer. It is given the definition of the term «emotional intelligence», revealed its origin. The work describes the main emotional intelligence skills: self-awareness, self-regulation, empathy, motivation, social skills. The author pays attention to Johari Window technique, which helps people better understand their relationship with themselves and others. The article gives a possibility to get acquainted with a list of questions which could be used to assess teacher's work in a class, content of the course, students' satisfaction with the course, recommendations of improving the course etc. These questions are divided into the 
following categories: 1) instructor-specific question themes; 2) course-specific question themes; 3) student self-evaluation questions; 4) open-ended questions. The author of the article also represents some emotional self-regulation strategies, which can be applied in a class. It is explained the difference between a teacher, who is a leader and a usual teacher, who is just an executor of the demanded actions. There is an example of a questionnaire, which helps to determine leader's style.

According to Hersey and Blanchard Situational Leadership Theory a leader's ability to lead depends upon situation factors. These scientists focused a great part of their research on the characteristics of followers in determining appropriate leadership behaviours. According to this theory, leader's styles are divided into: directing, coaching, supporting, delegating. The author also explains the difference between a relationoriented and a task-oriented leader.

Key words: emotional intelligence, university lecturer, leader's style, leadership behavior, questionnaire.

Introduction. Economic development of any country depends greatly on world view of its citizens. Personality, professional, ideological qualities of specialists are greatly influenced by educational system, atmosphere in educational institution, by teachers themselves. In this article we'll try to highlight competencies of emotional intelligence of a university lecturer; discuss why it's important for a teacher to inspire students and to be a leader for them.

Emotional intelligence became the object of scientific investigations in the works of such scientists as D. Goleman, D. Clark, T. Bradberry, C. Stanley, J. Mayer, D. Caruso, H. Gardner, D. Ljusin, G. Garskova, A. Leontiev, I. Andreeva, A. Pankratova, T. Berezovska, S. Mogilyasta and others. To understand the connection between emotional intelligence and leadership we should also refer to the works of scientist who devoted their studies to leadership. So, different aspects of leadership were studied by such American and European scientists: P. Hersey, K. Blanchard, J. Rost, F. Fielder, R. Bolden, B. Kellerman, C. Stevens, R. Heifetz, B. Johansen, G. Homans, S. Mitchell, J. Hemphill and others. Different aspects of educational leadership were discussed in details in the works of such scientists as K. Leithwood, E. Samier, P. Milley, M. Wheatley, S. Kalashnikova, L. Karamushka, S. Kurbatov, N. Volkova, O. Romanovskij, V. Krizhko and others.

Research methods and techniques. Research methods are the analysis of scientific and pedagogical literature in order to determine importance and connection between emotional intelligence and university leadership.

Results and discussions. Emotional intelligence is one of the main characteristics of the leader. This term means the ability to understand and manage your emotions as well as recognize and influence the emotions of people around you. It was first coined by researches John Mayer and Peter Salovey in 1990, later psychologist Daniel Goleman popularized it. More than a decade ago, Goleman highlighted the importance of emotional intelligence in leadership, telling the Harvard Business Review, «The most effective leaders are all alike in one crucial way: They all have a high degree of what has come to be known as emotional intelligence» (Lauren Landry, 2019).

We'll highlight five emotional intelligence skills, each leader should have (Lauren Landry, 2019): 
- Self-Awareness it's a clear understanding of your strength, limitations, emotions, beliefs. Very often, people who have low level of selfawareness make worse decisions, can deal worse with conflicts.

Speaking about self-awareness we should mention Johari window (Chart 1), a technique, which helps people better understand their relationship with themselves and others. It was created by scientists Josef Luft and Harrington Ingham and got its name «Johari» by a combination of their first names (Johari Window. Wikipedia; Self-awareness. Wellbeing Support Services):

Chart 1

\begin{tabular}{|l|l|}
\hline Known Self & $\begin{array}{l}\text { Hidden Self } \\
\text { Things we know about ourselves and } \\
\text { others know about us. }\end{array}$ \\
\hline $\begin{array}{l}\text { Blind Self } \\
\text { Things others know about us that we do not know. }\end{array}$ \\
$\begin{array}{l}\text { nnknown Self } \\
\text { not know. }\end{array}$ & $\begin{array}{l}\text { Things neither we nor others know about } \\
\text { us. }\end{array}$ \\
\hline
\end{tabular}

It's useful for instructors to know students' attitude towards their course and their personality in general. Therefore, there can be presented the list of approximate questions to assess teacher's work in a class, content of the course, students' satisfaction with the course, recommendations of improving the course etc. The questions can be divided into the following categories (Course Evaluation Question Bank):

1) Instructor-Specific Question Themes

a) the instructor presented content in an organized manner;

b) the instructor was helpful when I had difficulties or questions;

c) the instructor provided clear constructive feedback;

d) the instructor encouraged student questions and participation;

e) the instructor encouraged participation;

f) mandatory: considering both the limitations and possibilities of the subject matter and the course, how would you rate the overall effectiveness of this instructor?

2) Course-Specific Question Themes

a) the course was effectively organized;

b) the course developed my abilities and skills for the subject;

c) the course (or section) developed my ability to think critically about the subject;

d) considering both the limitations and possibilities of the subject matter and the course, how would you rate the overall effectiveness of this course?

3) Student Self-Evaluation Questions

a) how many classes (or section) sessions did you attend?

b) on average, how many hours per week have you spent on this course (or section), including attending classes, doing readings, reviewing notes, writing papers, and any other course-related work?

c) how satisfied were you with your effort in this course (or section)?

4) Open-Ended Questions

a) please identify what you consider to be the strengths of the course (or section);

b) please identify area(s) where you think the course (or section) could be improved; 
c) feedback for other students: What advice would you give to another student who is considering taking this course (or section)?

- Self-regulation is the ability to manage your emotions, impulses, behaviours. (Lauren Landry, 2019).

To create positive atmosphere in a class its necessary for teachers to regulate their emotions by using effective strategies. The main emotional self-regulation strategies which help to regulate emotions and maintain healthy learning atmosphere (Zineb Djoub , 2018):

1) setting a professional code of conduct;

2) being self-confident;

3) equipping yourself with the tools to feel secure (learning more about your students; being well-prepared is essential to feel secure and comfortable; learning how to deal with embarrassing situations; collaborating with your colleagues);

- Empathy is the ability to understand another person's emotions, experience. By empathy we mean (Morin Amanda):

1) putting aside judgment;

2) trying to understand the student's feelings;

3) communicating to understand. For students, who learn and think differently is very important to feel that they are understood and supported. It helps them to stay motivated, increase self-awareness.

While speaking about leadership, we should pay attention to motivation. Motivation is the ability to inspire yourself and your students to work. It's important to be an example for others, take the initiative, stay optimistic during turbulent times. Unfortunately, many teachers come to their work daily without any enthusiasm. Consequently, leaders and usual workers behave differently at work (Lauren Landry, 2019). There is a chart (chart 2) to illustrate it:

Chart 2

\begin{tabular}{|l|l|l|}
\hline & - Leader & $\begin{array}{l}\text { - A person without leadership } \\
\text { characteristics }\end{array}$ \\
\hline Purpose & - Dealing with change & - Dealing with complexity \\
\hline Focus & - Thinking & - Doing \\
& - Change and innovation & - Execution and implementation \\
& - «Doing the right things» & - «Doing the right things» \\
\hline Main skills & - Formulating visions & - Planning projects \\
& - Aligning people & - Organizing people \\
& - Motivating and inspiring & - Monitoring progress and \\
& - Influencing & - performance \\
& - Puture & - Present \\
& - Long-term & - Short-term \\
\hline Orientation & - High level & - Ground level \\
\hline Daily work & - Change & - Order \\
\hline Seeks to & - Newness & - Consistency \\
achieve & - Movement & - Stability \\
\hline
\end{tabular}

- Social skills the way you perceive your emotions, communicate with others. 
It should be noted, that there are different types of leaders. A relationoriented leaders pay attention to people, create atmosphere of mutual trust and respect, try to learn needs of subordinates. A task-oriented leader determines the direction of activity and work norms. Fred Fielder studied the relationship between leadership style, situation and results of group work, he came to the further conclusion. Leader, who is task-oriented is more successful in very favourable and very unfavourable situations. As for favourable situations, all subordinates support the leader and agree with him (her), besides he has a power. All those conditions are necessary to structure the work of subordinates in the right direction. Similarly, very unfavourable situations also need structure and right direction of activity. Relation-oriented leader is more effective in average difficulty situations, because communication skills are very important here. To solve the problems, a real leader should know which relation he (she) has with subordinates, whether the situation is favourable or unfavourable and choose appropriate style of behaviour (Kazakevich O., 2019; Daft R., Lein P., 2007).

Leader's style (type) can be determined by questionnaire. Here are given examples of some adjectives (chart 3 ). If leaders while talking about employees use mostly positive characteristics it means they are focused on the relationship. These people show care towards others. And vice versa, when leader uses negative adjectives while describing employees, they are rather task-oriented. This model can be applied to relationship between a university teacher and students. Examples of adjectives (Kazakevich O., 2019; Daft R., Lein P.,2007):

Chart 3

\begin{tabular}{|l|r|}
\hline \multicolumn{2}{|c|}{ Adjectives } \\
\hline approachable & guarded person \\
\hline conflict & harmonious \\
\hline effective & inefficient \\
\hline confident & unconfident \\
\hline communicable & frowning \\
\hline
\end{tabular}

According to Hersey and Blanchard Situational Leadership Theory (Hersey and Blanchard Situational Leadership Model, 2020) a leader's ability to lead depends upon situation factors. These scientists focused a great part of their research on the characteristics of followers in determining appropriate leadership behaviours. In the chart below (Chart 4) there are given the characteristics of the followers and appropriate leader style which is more suitable in the concrete situation.

Chart 4

\begin{tabular}{|l|l|}
\hline \multicolumn{1}{|c|}{$\begin{array}{c}\text { Levels of the followers'(students) } \\
\text { performance readiness }\end{array}$} & \multicolumn{1}{c|}{ Appropriate leader's style } \\
\hline Low & directing \\
\hline Middle & coaching \\
\hline High & supporting \\
\hline Very high & delegating \\
\hline
\end{tabular}


We'll try to concentrate on these styles more deeply (Hersey and Blanchard Situational Leadership Model, 2020):

Directing offers step-by-step instructions, clear explanation of the consequences, close supervision. The task should be clearly defined and the stages of the process are easy to follow. This is important because the leader believes that the followers either do not know what to do or are unwilling and require therefore a certain degree of coercive power. Blanchard also believes that this style should be also used for followers who are highly «Enthusiastic beginners». They have the motivation to do the task but still lack the competence, which increases their need for directive behaviour.

Coaching. This leadership style is the high directive and high supportive leadership style. Hersey argued that this style is needed for followers who are willing, but not able to perform a task. Blanchard, however, believes this style is necessary for followers, who used to be highly enthusiastic in the beginning but who lost confidence because their competences are failing them.

Supporting. This style shows high supportive behaviours, but low directive behaviours. This may involve listening, praise and a high level of interaction between leader and follower. In addition, the leader puts a high level of trust in the follower to achieve the day-to-day tasks as the follower's competence has also grown over time. The leader believes that the subordinate is capable enough of achieving the required tasks largely independently.

Delegating. This leadership style assumes a low supportive and a low directive behaviour. The subordinate is perfectly able and willing to perform the tasks independently and with great responsibility. The leader can further encourage autonomy, while keeping an eye on not overloading the follower with responsibility. For this type of followers it is thus important as a leader to keep observing and monitoring them, in order to provide the necessary support if needed.

An interesting fact, a research, conducted among 195 leaders from more than 30 global organizations indicates, that all leaders have common competencies (Sunnie Giles, 2015):

- high ethical standards and providing a safe environment;

- empowering individuals to self-organize;

- promoting connection and belonging among employees;

- open to new ideas and experimentation;

- committed to the professional and intellectual growth of employees.

Conclusions. Studying the phenomenon of university leadership, the following conclusion can be made: a university leader should have high level of emotional intelligence. It's very important for them to develop the ability to inspire and motivate students, define and structure the work, create positive collaborative atmosphere. Teachers should be interested in the intellectual growth of the students but to be one step ahead them. It's useful for teachers to have feedback about their course and soft skills. And as a result, to work constantly on personal and professional growth. University teachers, should 
be psychologists to some extent. Depending on the characteristics of a student, they should apply different leadership styles: directing, coaching, supporting, delegating.

\section{Література}

1. Безкоровайна Л. В. Концепція підготовки майбутніх фахівців 3 туризмознавства у вищих навчальних закладах. Освітологічний дискурс : електронне наукове фрахове видання. 2017. № 1-2. C. 67-78. URL : http://nbuv.gov.ua/UJRN/osdys 2017 1-2_8.

2. Безкоровайна Л. В. Теоретичні і методичні засади професійної підготовки майбутніх фахівців з туризмознавства у вищих навчальних закладах : дис. ... д-ра пед. наук: 13.00.04 / Запорізький національний університет. Запоріжжя, $2018 . \quad 713 \mathrm{c.} \quad$ URL: http://phd.znu.edu.ua/page/dis/09 2018/Bezkorovaina dis.pdf

3. Косовщук А., Безкоровайна Л. Науково-дослідна робота у професійній підготовці майбутніх фахівців з туризму в закладах вищої освіти. Наукові записки Бердянського державного педагогічного університету. Педагогічні науки. 2021. Вип. № 1. Бердянськ : БДПУ. С. 248-255.

Літвінова-Головань О. П. Формування готовності майбутніх фахівців із туризму до організації та проведення заходів спортивно-розважальної анімації : дис. ... канд. пед. наук: 13.00 .04 / Запорізький національний університет. 3 Запоріжжя, 2020.206 c. URL : http://phd.znu.edu.ua/page//dis/09 2020/Litvinova-Golovan dis.pdf

4. Про вищу освіту: Закон України від 01.07.2014 p. № 1556-VII. Дата оновлення: 16.04.2017. URL : http://zakon2.rada.gov.ua/laws/show/1556-18 Про Національну стратегію з оздоровчої рухової активності в Україні на період до 2025 року «Рухова активність - здоровий спосіб життя здорова нація», Указ Президента України від 09.02.2016. URL : https://zakon.rada.gov.ua/laws/show/42/2016

Про схвалення Концепції популяризації України у світі та просування інтересів України у світовому інформаційному просторі від 11 жовтня 2016 р. № 739-p Київ. URL : https://www.kmu.gov.ua/ua/npas/249407991

Про схвалення Стратегії розвитку туризму та курортів до 2026: розпорядження Кабінету Міністрів України від 16.03.2017 р. №168-р. Урядовий портал. $2017 . \quad$ № 168-2017-p. URL: https://www.kmu.gov.ua/ua/npas/249826501

5. Про туризм: Закон України від 15.09.1995 р. № 324/95-ВР. Відомості Верховної Ради України. 1995. № 31. Ст. 241. Із змінами, внесеними згідно із Законом № 222-VIII (222-19) від 02.03.2015 р., Відомості Верховної Ради України. 2015. № 23. ст. 158. URL : http://zakon2.rada.gov.ua/laws/show/1282-15

\section{References}

1. Bezkorovaina, L. V. (2017). Kontseptsiia pidhotovky maibutnikh fakhivtsiv z turyzmoznavstva $u$ vyshchykh navchalnykh zakladakh [The concept of training future specialists in tourism in higher education]. Osvitolohichnyi dyskurs : elektronne naukove fakhove vydannia. Kyiv, № 1-2. S. 67-78. [in Ukrainian].

2. Bezkorovaina, L. V. (2018). Theoretical and methodological basis of the professional training of the future masters of tourism in higher educational institutions [Theoretical and methodological principles of professional training of future specialists in tourism in higher education]. Thesis for a doctoral degree in pedagogical sciences, 
Zaporizhzhia: Zaporizhzhia National University. [in Ukrainian].

3.Kosovshchuk, A., Bezkorovaina, L. (2021). Naukovo-doslidna robota $u$ profesiinii pidhotovtsi maibutnikh fakhivtsiv z turyzmu $v$ zakladakh vyshchoi osvity [Research work in the training of future tourism professionals in higher education institutions]. Naukovi zapysky Berdianskoho derzhavnoho pedahohichnoho universytetu. Pedahohichni nauky - Scientific notes of Berdyansk State Pedagogical University. Pedagogical sciences, 1, 248-255. [in Ukrainian].

4. Litvinova-Holovan, O. P. (2020). Formuvannia hotovnosti maibutnikh fakhivtsiv iz turyzmu do orhanizatsii ta provedennia zakhodiv sportyvno-rozvazhalnoi animatsii [Formation of readiness of future specialists in tourism to organize and hold events of sports and entertainment animation]. Thesis for a Candidate degree in pedagogical sciences, Zaporizhzhia: Zaporizhzhia National University [in Ukrainian].

5. Pro vyshchu osvitu [On higher education]: Zakon Ukrainy vid 01.07.2014 r. № 1556-VII. URL : http://zakon2.rada.gov.ua/laws/show/1556-18 (Data zvernennia: 16.04.2017). [in Ukrainian].

6. Pro Natsionalnu stratehiiu z ozdorovchoi rukhovoi aktyvnosti $v$ Ukraini na period do 2025 roku "Rukhova aktyvnist - zdorovyi sposib zhyttia - zdorova natsiia» [On the National Strategy for Physical Activity in Ukraine until 2025 «Physical activity a healthy lifestyle - a healthy nation»] (2016) Ukaz Prezydenta Ukrainy vid 09.02.2016. Kyiv [in Ukrainian].

7.Pro skhvalennja Koncepciji populjaryzaciji Ukrajiny u sviti ta prosuvannja interesiv Ukrajiny u svitovomu informacijnomu prostori (2016) [On approval of the Concept of popularization of Ukraine in the world and promotion of Ukraine's interests in the world information space] Kyjiv. [in Ukrainian]

8. Pro skhvalennja Strateghiji rozvytku turyzmu ta kurortiv do 2026 (2017) [On approval of the Strategy for the development of tourism and resorts until 2026], Kyjiv. [in Ukrainian].

9. Pro turyzm (1995) [About tourism] Zakon Ukrajiny, Kyjiv [in Ukrainian].

\section{АНОТАЦІЯ}

Стаття присвячена висвітленню концептуальних засад побудови та розвитку вищих педагогічних навчальних закладів України на початку XX століття. Саме в чей період педагогічна освіта будувалась як на власне українських педагогічних традиціях, так і на західних технократичнопрагматичних концептуальних поглядах на спрямованість педагогічної системи. Автором доведено, що 1920-их роках концепція педагогічної освіти була відображена в новій моделі освітньої системи, видах навчальних закладів, що готували педагогів, наступності навчання, створення профрільних вертикалей, нових фрормах, методах $і$ засобах навчання, відродженням педагогічної практики та стажування.

У статті розглянуті та проаналізовані три етапи формування вищих педагогічних закладів в Україні на початку $X X$ століття: перший етап передбачав жорстке централізоване управління вищими навчальними закладами, надмірне втручання партійних структур. Другий етап відзначався намаганням керівництва зробити поступки викладачам, професурі, студентам, залучаючи їх до безпосередньої участі у роботі нових органів управління вищою школою. Третій етап характеризувався намаганням повернутися до адміністративних та централізованих методів керівництва. у статті з'ясовано, що в досліджуваній період замість Рад ВНЗ та факультетів з'являються суто статистичні та аморфні загальні збори, факультетські комісії, максимально посилюється адміністративна влада ректора та деканів. 
У статті прослідковано процес розгалуження внутрішньої структури педагогічних закладів освіти, коли були сформовані відділення соціального виховання, профресійної освіти, політичної освіти, заочної освіти, педологічні факультети та відділення з підготовки вчителів для шкіл національних меншин.

Ключові слова: вища освіта, освіта вчителів, інститут освіти, модель освіти, трудова школа. 